TARNOWSKIE STUDIA TEOLOGICZNE 37 (2018) NR 1-2, S. 31-46

http://dx.doi.org/10.15633/tst.3250

ks. Sylwester Jaśkiewicz ${ }^{1}$

KATOLICKI UNIWERSYTET LUBELSKI JANA PAWŁA II

\title{
Duch Święty jako Miłość w De Trinitate św. Augustyna
}

Pośród kategorii, jakimi posługuje się Augustyn, opisując Ducha Świętego znamienne miejsce zajmują dwie: dar (donum) i miłość (dilectio et caritas)². Skoncentrowanie się w pierwszej kolejności na miłości, której w rzeczywistości nie można oddzielić od kategorii daru w charakterystyce trzeciej Osoby Trójcy Świętej, ma uwydatnić jeden z niezwykle ważnych wymiarów nauki o miłości myśliciela z Tagasty, z którą powiązał on Ducha Świętego na długo wcześniej zanim podjął się systematycznej refleksji nad tajemnicą Trójcy Świętej ${ }^{3}$. Już bowiem na progu swojego chrześcijańskiego życia, w rozmowie z Ewodiuszem na temat istoty duszy Augustyn nazywa Ducha Świętego „niezmienną Miłością"4. Choć trudno odpowiedzieć, skąd i dlaczego zrodziła się ta idea $\mathrm{w}$ umyśle myśliciela $\mathrm{z}$ Tagasty, to jednak jej najbardziej dojrzała forma, jaką znajdujemy w pisanym przez dwadzieścia lat traktacie De Trinitate 5 , pozwala dostrzec całą niespotykaną dotąd oryginalność biskupa Hippony

1 Ks. Sylwester Jaśkiewicz - teolog dogmatyk, kapłan diecezji radomskiej. Jest wykładowcą w Wyższym Seminarium Duchownym w Radomiu (KUL) oraz na UKsw w Warszawie. Od lat interesuje się licznymi dziełami św. Augustyna i ich przesłaniem. Jest autorem licznych artykułów z zakresu: eklezjologii, trynitologii, charytologii oraz eschatologii.

2 Ich zwięzłą, a zarazem dogłębną charakterystykę zarysowuje w swym artykule ks. prof. A. Żurek, Duch Święty jako Dar i Miłość według świętego Augustyna, „Tarnowskie Studia Teologiczne 17 (1998), s. 37-46.

3 Por. A. Żurek, Duch Święty..., s. 41.

4 Augustyn, O wielkości duszy xxxiv.77, tłum. D. Turkowska, w: Św. Augustyn. Dialogi filozoficzne, oprac. W. Seńko, Kraków 2001, s. 415.

5 Por. B. Częsz, Pneumatologia Ojców Kościoła, w: Duch, który jednoczy. Zarys pneumatologii, red. M. Marczewski, Lublin 1998, s. 113; W. Eborowicz, Rzut oka na pneumatologię św. Augustyna, „Vox Patrum” 8 (1988) z. 14, s. 197; S. Jaśkiewicz, „Ecce Trinitas Deus meus, Pater et Filius et Spiritus Sanctus”. Nauka o Boskiej Trójcy na podstawie „Wyznañ” św. Augustyna, „Collectanea Theologica” 78 (2008) nr 1, s. 5-30; S. Jaśkiewicz, Św. Augustyn - poszukiwanie Boga, Katowice 2012, s. 168-173; S. Kowalczyk, Człowiek i Bóg w nauce świętego Augustyna, Warszawa 1987; R. Williams, Trinitate, De, w: Agostino. Dizionario enciclopedico, ed. A. Fitzge- 
i jego wkład w rozwój pneumatologii, a zarazem w chrześcijańskie rozumienie miłości na Zachodzie. To właśnie w tym dziele pobudzając do poszukiwania i refleksji, stawia on wymowne pytanie: „Jakim innym imieniem należy właściwie i z osobna oznaczać Ducha Świętego?"

\section{Pismo Święte głosi, że „Bóg jest miłością”}

Podstawowym źródłem prawdy, jaką Bóg przekazał ludzkości, jest Objawienie spisane w obu Testamentach (scripturae), które w czasach Augustyna było powszechnie bardziej znane uchem niż okiem ${ }^{7}$. O obraniu za największy autorytet powagi Pisma Świętego spisanego przez sługi Ducha Świętego ${ }^{8}$ biskup Hippony mówi już na początku swego dzieła ${ }^{9}$. Z wielką uwagą stara się śledzić sposób wyrażania się ksiąg świętych, a jeszcze bardziej zawarte w nich prawdy. Autor De Trnitate nie tylko podkreśla, że Pismo Święte chwali i wysławia miłośćc ${ }^{10}$, ale słowa św. Jana „Bóg jest miłością” ( $1 \mathrm{~J}$ 4, 8. 16) przyjmuje za punkt odniesienia w głębszej refleksji nad miejscem i rolą Ducha Świętego w wewnętrznym życiu Trójcy ${ }^{11}$. Wyznaje z pokorą: „Lecz kiedy doszliśmy do miłości, o której Pismo św. mówi, że to Bóg $(1 \mathrm{~J}$ 4,16), wówczas tajemnica rozjaśniła się nieco, gdyśmy dostrzegli triadę kochającego, przedmiotu jego umiłowania i samej miłości. Ta niewymowna światłość olśniewała nasz wzrok, a słabość naszego umysłu nie mogła tego dosięgnąć. Przeto przerwaliśmy dociekania i zwróciliśmy się ku naszej własnej duszy stworzonej na obraz Boży (Rdz 1,27), znajdując w niej

rald, edizione italiana a cura di L. Alici, A. Pieretti, Roma 2007, s. 1396-1405; A. Żurek, Duch Swięty..., s. 41.

${ }^{6}$ Augustyn, O Trójcy Świętej viI.3.6, tłum. M. Stokowska, Kraków 1996, s. 245. Imię albo też imię własne jest uściśleniem jakiejś nazwy. Biskup Hippony wiedział np. doskonale, że „Nazwą «Prawa» albo «Zakonu» oznacza się czasami wszystkie księgi Starego Testamentu. [...] Czasami zaś tym, co oznacza się nazwą Prawa czy Zakonu jako imieniem własnym, jest Prawo dane Mojżeszowi. [...] Ogólnie Prawo obejmuje również Proroków i Psalmy, we właściwym znaczeniu - Prawo dane Mojżeszowi. [...] Można by przytoczyć więcej takich przykładów, więcej słów, które raz oznaczają cały zespół rzeczy, a innym znów razem dotyczą ściśle określonych rzeczy" (O Trójcy Świętej xv.17.30, s. 500-501).

7 Por. J. J. O’Donnell, Bibbia, w: Agostino. Dizionario enciclopedico, s. 302.

${ }^{8}$ Por. S. Jaśkiewicz, O potrzebie i znaczeniu historii według świętego Augustyna, „Studia Regionalne" 1 (2007), s. 162-166; J. Królikowski, Dotknięci Duchem Świętym. Metafory pneumatologiczne w interpretacjach Ojców Kościoła, „Scripture Lumen” 8 (2016), s. 249.

9 Por. Augustyn, O Trójcy Świętej I.2.4, s. 26.

${ }^{10}$ Por. Augustyn, O Trójcy Świętej viII.10.14, s. 284.

${ }_{11}$ Por. A. Żurek, Duch Święty..., s. 41. 
bliższy nam przedmiot badań, pozwalający nieco odpocząć zbyt napiętej uwadze"12. Zawarta w Piśmie Świętym prawda jest dla Augustyna światłem, które pozwala mu wejść w sferę tajemnicy samego Boga. W istocie bowiem „Duch Święty - według Pisma Świętego - nie jest Duchem samego Ojca ani samego Syna, ale jest Duchem Ich obydwóch. Dlatego nasuwa się nam myśl o wspólnej miłości Ojca i Syna, którą oni nawzajem się miłują"13. Wiele spośród prawd zawartych w Piśmie Świętym wyrażone jest w sposób, który nie tylko pobudza, lecz wręcz inspiruje do dalszego poszukiwania. Na wiele sposobów „Pismo zachęca nas do ćwiczenia umysłu, gdyż chodzi tu nie o rzeczy bezpośrednio dla nas dostępne, ale o tajemnice, których trzeba dociekać w ukryciu i z ukrycia wydobywać, co nas zmusza do coraz większego wysiłku. Pismo św. nie mówi o tym, że Duch Święty jest miłością. Gdyby to było tam powiedziane, to niemała część kwestii niniejszej byłaby przez to wyjaśniona. Lecz mówi ono: «Bóg jest miłością» $(1 \mathrm{~J} 4,16)$. Tak więc nie jest to wyraźne i musimy szukać, czy to Ojciec, czy Syn, czy Duch Święty jest miłością, czy też cała Trójca?"14. Nie tylko w języku mówionym, ale i pisanym jest wiele takich słów, „które raz oznaczają cały zespół rzeczy, a innym razem dotyczą ściśle określonych rzeczy. Lecz sprawa jest tak jasna, że nie potrzebuje dłuższych wywodów. Dałem te wyjaśnienia, żeby ktoś nie sądził, że bezpodstawnie nazywam Ducha Świętego miłością, gdy można i Boga Ojca, i Boga Syna również nazwać miłością" ${ }^{15}$. Pismo Święte ukazuje działanie Ducha Świętego w szerokiej perspektywie historii zbawienia, pozostawiając jakby w sferze tajemnicy Jego osobliwość, Jego odrębność w wewnętrznym, wiecznym życiu Trójcy.

\section{Tajemnica miłości trynitarnej}

Tajemnica jedynego Boga, będącego Trójcą: Ojcem, Synem i Duchem Świętym w wymiarze Jego wewnętrznego życia zawsze fascynowała Augustyna. Punktem wyjścia jego rozważań jest głęboko zakorzenione w Tradycji łacińskiej wyznanie wiary w Trójcę Świętą ${ }^{16}$, a więc prawda o tym, że Ojciec, Syn i Duch Święty są jedną substancją albo lepiej istotą, a przy tym różnią się między sobą jako

2 Augustyn, O Trójcy Świętej xv.6.10, s. 470.

${ }^{13}$ Augustyn, O Trójcy Świętej xv.17.27, s. 497. Por. A. Żurek, Duch Święty..., s. 43.

${ }^{14}$ Augustyn, O Trójcy Świętej xv.17.27, s. 497.

15 Augustyn, O Trójcy Świętej xv.17.30, s. 500.

${ }^{16}$ Znamienny wkład, zwłaszcza poprzez wypracowanie terminologii i formuł: Trinitas, tres personae, una substania, wniósł zwłaszcza Tertulian. Por. Y. Congar, Wierzę w Ducha Świętego. 
Osoby ${ }^{17}$. Najwyższej Trójcy, która jest Bogiem, przysługuje pełnia życia: „Co bowiem nazywamy w Bogu życiem, to jest Jego istotą i naturą. Gdyż Bóg sam żyje życiem, jakim jest sam w sobie"18. Jedną z najważniejszych dla prawdy o Bogu-Trójcy kwestię, a więc kwestię Jego jedności i troistości zarazem, stara się Augustyn wyjaśnić dzięki pojęciu "relacja” (schesis, relatio - stosunek, odniesienie $)^{19}$. Biskup Hippony dochodzi do wniosku, że „określenia, których się używa we właściwym znaczeniu dla poszczególnych Osób w tejże Trójcy, nigdy nie odnoszą się do samych Osób, ale wskazują albo na ich wzajemne odnoszenie się jednych względem drugich, albo na ich stosunek do stworzenia. Jasne więc, że są to oznaczenia relatywne, a nie substancjalne. Tak bowiem jak Trójcę nazywa się jednym Bogiem, wielkim, dobrym, wiecznym i wszechmocnym, tak samo można mówić, że Bóg jest sam swoją Boskością, sam swoją wielkością, dobrocią, wiecznością i swoją wszechmocą" ${ }^{20}$. Bóg dla Augustyna to Trójca, a Trójca to Ojciec, Syn i Duch Święty razem wzięci. Choć każda z Osób Trójcy jest tym samym, jednym Bogiem, to „Nie można jednak nazwać Trójcy «Ojcem», chyba że przenośnie w odniesieniu do stworzenia, ze względu na przybranie synowskie. W każdym razie słów Pisma: «Słuchaj, Izraelu! Pan, Bóg twój, Pan jeden jest» (Pwt 6,4), nie należy rozumieć z wyłączeniem Syna albo Ducha Świętego, gdyż jedynego Pana, Boga naszego, słusznie nazywamy również Ojcem naszym, bo nas odrodził przez swoją łaskę. Ale w żaden sposób nie można Trójcy nazwać Synem" ${ }^{21}$.

Gdy myślimy o miłości w odniesieniu do Deus-Trinitas, to w pierwszej kolejności należy wziąć pod uwagę, że „W Bogu jedna doskonałość znaczy tyle, co wszystkie, jak to ma miejsce z mądrością. Doskonałości w taki sposób należą do natury każdej z Osób, że każda z nich - będąc prostą i niezmienną substancją - jest tym, co posiada. Jeśli zrozumiano te rzeczy i okazały się one

Duch Święty w „ekonomii”. Objawienie i doświadczenie Ducha, t. 1, tłum. A. Paygert, Warszawa 1995, s. 124-125; E. TeSelle, Spirito Santo, w: Agostino. Dizionario enciclopedico, s. 1321.

${ }_{17}$ Por. F. Bolgiani, Spirito Santo, w: Dizionario patristico e di antichità cristiane, diretto da A. Di Berardino, t. 2, Casale Monferrato 1983, kol. 3295; W. Eborowicz, Rzut oka..., s. 197198; E. TeSelle, Spirito Santo, s. 1323.

${ }_{18}$ Augustyn, O Trójcy Świętej XIV.5.7, s. 466.

19 Por. C. S. Bartnik, Dogmatyka katolicka, t. 1, Lublin 200o, s. 208; F. Bolgiani, Spirito Santo, kol. 3295; H. Chadwick, Augustyn, tłum. T. Szafrański, Warszawa 200o, s. 136; S. Jaśkiewicz, Św. Augustyn..., s. 169; B. Studer, Dio salvatore nei Padri della chiesa, Roma 1986, s. 242.

${ }^{20}$ Augustyn, O Trójcy Świętej v.11.12, s. 208.

${ }^{21}$ Augustyn, O Trójcy Świętej v.11.12, s. 208. 
prawdziwe - o ile można w tak wzniosłych tajemnicach coś zobaczyć i coś wnioskować - to nie wiem, dlaczego nie można by nazwać miłością i Ojca, i Syna, i Ducha Świętego, gdyż razem są jedną miłością, tak jak mówimy, że mądrością jest i Ojciec, i Syn, i Duch Święty, stanowiąc razem jedną mądrość, a nie potrójną mądrość"22. Wszystkie doskonałości, które przypisujemy Bogu, nie przeciwstawiają ani nie odróżniają poszczególnych Osób Trójcy, gdyż są one właściwościami istoty. Jedna miłość w Bogu jest miłością istotową, wspólną Ojcu, Synowi i Duchowi Świętemu. W odniesieniu jednak do Ducha Świętego należy podkreślić, że „jest czymś we wszystkim wspólnym Ojcu i Synowi. Ta więź wspólnoty jest z Nimi współistotna i współwieczna. Wprawdzie miano przyjaźni jest dla niej stosowne, lepiej jednak powiedzieć o niej: miłość. Jest ona substancjalna, bo Bóg jest substancją: «Bóg jest miłością», jak mówi Pismo św. $(1 \mathrm{~J}$ 4,16). Tak jak jest substancją wraz z Ojcem i Synem, tak samo Miłość jest wraz z Nimi wielka, dobra, święta i dzieli z Nimi wszystko, co do Nich samych się odnosi. Bo w Bogu nie ma różnicy pomiędzy bytem a tym, że jest wielki, dobry itp. Gdyby tutaj miłość była mniej wielka niż mądrość, to nie dorównałaby własnemu bytowi. Zatem jest równa. I mądrość też musi dorównać miłości. A że mądrość jest równa Ojcu, jak to przedtem wyjaśniliśmy, zatem i Duch Święty jest równy. A jeśli jest równy, to we wszystkim równy $\mathrm{z}$ racji najwyższej prostoty tej substancji” ${ }^{23}$.

Niektóre słowa, jakimi posługujemy się w odniesieniu do poszczególnych Osób Trójcy, tak jak np. „Słowa «miłość» (caritas) i Duch mają sens ogólny lub istotowy, ale także sens ścisły i osobowy" ${ }^{24}$. Wyjaśnia biskup Hippony: „A jednak w Trójcy Świętej nie bez podstawy nazywamy Słowem Bożym tylko Syna, Darem tylko Ducha Świętego, a tylko Ojca tym, z którego rodzi się Słowo, a głównie pochodzi Duch Święty. [...] Podobnie bowiem Słowo Boże otrzymuje właściwe Mu miano Mądrości Bożej, chociaż mądrością są także i Ojciec, i Duch Święty. Jeżeli więc jednej z trzech Osób ma być nadane imię miłości, to do której ono lepiej pasuje niż do Ducha Świętego? Co nie znaczy, że w tej najwyższej i niezłożonej naturze można rozdzielać miłość od istoty; sama bowiem istota Boża jest miłością, a miłość istotą czy to w Ojcu, czy w Synu, czy w Duchu Świętym. A jednak możemy Duchowi Świętemu przypisywać

${ }^{22}$ Augustyn, O Trójcy Świętej Xv.17.28, s. 498. Por. S. Jaśkiewicz, Ecce Trinitas..., s. 16; A. Żurek, Duch Święty..., s. 41.

${ }^{23}$ Augustyn, O Trójcy Świętej VI.5.7, s. 225.

${ }^{24}$ Y. Congar, Wierzę w Ducha Świętego. Duch Święty w „ekonomii”..., s. 129-130. 
właściwie imię miłości”"25. Augustyn, koncentrując się na miłości w życiu trynitarnym, nie korzysta z pojęcia przyjaźni ${ }^{26}$.

W miłości Augustyn widzi podstawę i uzasadnienie Boskiej Trójcy, a więc istnienia trzech Osób w Bogu. Nie mniej ani nie więcej, ale właśnie „jest Ich tylko Troje: jeden miłujący Tego, który z Niego pochodzi, jeden miłujący Tego, z którego pochodzi, i sama Ich miłość. Jeśli ta miłość nie jest Bogiem, to w jaki sposób «Bóg jest miłością»? A jeśli nie jest substancją, to w jaki sposób Bóg jest substancją?"27. W rzeczywistości Augustyn raczej tylko okazyjnie posługuje się triadą: kochającego, kochanego i ich miłości w odniesieniu do Ducha Świętego w Trójcy, a jego dojrzałe rozumienie Trójcy Świętej uwydatnia, że obok Ducha Świętego tak Ojciec, jak Syn jest duchem, podobnie, jak i świętym jest Ojciec i Syn, a przy tym Duch Święty, będąc wzajemną miłością Ojca i Syna, jest nazywany słusznie tym, czym Oni są wspólnie ${ }^{28}$.

\section{Duch Święty jest Duchem Ojca i Syna}

Pierwszym pytaniem, jakie Augustyn stawia, a właściwie przytacza jako najczęściej stawiane w odniesieniu do Ducha Świętego, jest: „Jak się to dzieje, że jest w Boskiej Trójcy Duch Święty, nie zrodzony ani przez Ojca, ani przez Syna, ani przez Nich razem, a jednak będący Duchem i Ojca i Syna?" 29 W kwestii pochodzenia Ducha Świętego Augustyn podobnie jak przed nim w świecie łacińskim Tertulian, Hilary z Poitiers, Mariusz Wiktoryn czy Ambroży, stwierdza wyraźnie, że Duch Święty jest Duchem Ojca i Syna. Biskup Hippony, stając w wyraźnej opozycji do teogonii mitycznych ${ }^{30}$, już na początku pierwszej księgi wyjaśnia: „A więc nie ma trzech bogów, ale jest jeden Bóg, chociaż Ojciec Syna zrodził i dlatego Syn nie jest tą samą Osobą, co Ojciec; i Ojciec nie jest Synem przez Siebie zrodzonym, a Duch Święty nie jest ani Ojcem, ani Synem, lecz jest Duchem Ojca i Syna, współrównym Im i należącym do jedności Trójcy" ${ }^{31}$.

\footnotetext{
${ }^{25}$ Augustyn, O Trójcy Świętej xv.17.29, s. 498-499.

${ }^{26}$ Por. Y. Congar, Wierzę w Ducha Świętego. Duch Święty w „ekonomii”..., s. 131.

27 Augustyn, O Trójcy Świętej vi.5.7, s. 225.

${ }^{28}$ Por. E. TeSelle, Spirito Santo, s. 1324.

${ }^{29}$ Augustyn, O Trójcy Świętej I.5.8, s. 32.

${ }^{30}$ Por. E. TeSelle, Spirito Santo, s. 1325.

${ }^{31}$ Augustyn, O Trójcy Świętej I.4.7, s. 30.
} 
Wyrażenie „Duch Święty” odnosi się zarówno do całej Trójcy Świętej, jak i do trzeciej Osoby. W pierwszej kolejności „wyrażenie «Duch Święty», zgodnie z tym, co napisano: «Duchem jest Bóg» (J 4,24), może odnosić się do całej Trójcy Świętej, bo i Ojciec jest duchem, i Syn, i Duch Święty. A ponieważ i Ojciec, i Syn, i Duch Święty są jednym Bogiem, i to Bogiem świętym, Bogiem, który jest duchem, przeto Trójcę Świętą można nazwać Duchem Świętym” " W odniesieniu do trzeciej Osoby Trójcy Świętej wyrażenie „Duch Święty” jest imieniem własnym. W takim znaczeniu „Duch Święty - nie jako Trójca, ale Ten, który jest w Trójcy, którego jako własnym imieniem nazywa się «Duchem Świętym» - oznacza relację, ponieważ i do Ojca, i do Syna się odnosi, gdyż Duch Święty jest Duchem i Ojca, i Syna. Lecz sama relacja nie okazuje się w tym imieniu. Natomiast okazuje się ona, kiedy się Go nazywa Darem Bożym (Dz 8,20). Jest bowiem Darem wzajemnym i Ojca, i Syna, bo i «od Ojca pochodzi» (J 15,26), jak Pan powiada, i to, co mówi Apostoł: «Kto Ducha Chrystusowego nie ma, ten do niego nie należy» (Rz 8,9), z pewnością do Ducha Świętego się odnosi" "33. Bycie Darem (donum) wpisane jest w naturę Ducha Świętego ${ }^{34}$. Choć o więzi (vinculum) pomiędzy Ojcem i Synem uczył już Mariusz Wiktoryn, pod którego wyraźnym wpływem był Augustyn, to jednak dopiero biskup Hippony ujmuje pochodzenie Ducha Świętego jako „dar”, a Jego samego jako Dar sam w sobie $e^{35}$. Duch Święty jest wspólnym Darem Ojca i Syna.

Pochodzenie trzeciej Osoby Boskiej od Ojca i Syna w niczym nie umniejsza prawdy o bóstwie Ducha Świętego. Augustyn podkreśla z naciskiem, że Duch Święty „O tyle jest Darem Bożym, o ile jest dany tym, którzy z Niego korzystają. Sam w sobie zaś jest Bogiem, chociaż nikomu nie jest dany, ponieważ jest Bogiem współwiecznym Ojcu i Synowi, zanim komukolwiek został udzielony. To zaś, że Ojciec i Syn dają Go, a On jest dany, nie czyni Go mniejszym z Nich. Tak bowiem jest dany - On, Dar Boży - jak też sam daje siebie samego jako Bóg. Bo nie można mówić, że nie jest samowładny, skoro Pismo św. mówi: «Duch tchnie, kędy chce» (J 3,8), a słowa św. Pawła już wspomniałem, że «wszystko to sprawia jeden i tenże Duch, udzielając każdemu z osobna jako

${ }^{32}$ Augustyn, O Trójcy Świętej v.11.12, s. 208. Por. E. TeSelle, Spirito Santo, s. 1324.

${ }_{33}$ Augustyn, O Trójcy Świętej v.11.12, s. 208-209.

${ }^{34}$ Por. S. Jaśkiewicz, Ecce Trinitas..., s. 26-28; E. TeSelle, Spirito Santo, s. 1322; A. Żurek, Duch Święty..., s. 39.

35 Por. L. Bouyer, Duch Święty Pocieszyciel. Duch Święty i życie w łasce, tłum. A. Liduchowska, Kraków 1998, s. 266-267; A. Kijewska, Święty Augustyn, Warszawa 2007, s. 190; A. Żurek, Duch Święty..., s. 38-41. 
chce» (1 Kor 12,11). Nie ma tu zależności dla Tego, który jest dany, ani wyższości Dających: panuje między Nimi doskonała harmonia (concordia)" ${ }^{\prime 36}$.

Duch Święty zawdzięcza swe pochodzenie Ojcu i Synowi, ale to, że Syn jest współpoczątkiem Ducha Świętego, w istocie pochodzi od Ojca, co Augustyn stara się podkreślić w nawiązaniu do tradycji greckiej poprzez użycie terminu principaliter. „A jednak w Trójcy Świętej nie bez podstawy nazywamy Słowem Bożym tylko Syna, Darem tylko Ducha Świętego, a tylko Ojca tym, z którego rodzi się Słowo, a głównie pochodzi Duch Święty. Mówię «głównie», ponieważ wiadomo, że i od Syna także Duch Święty pochodzi”"37. Pochodzenie Ducha Świętego od Syna łączy się zawsze z Ojcem. Wyjaśnia Augustyn: „A kiedy się mówi o pochodzeniu Ducha Świętego od Ojca, to trzeba rozumieć to w taki sposób, że pochodzi On również i od Syna, co jednak Syn otrzymał od Ojca. Jeśli bowiem wszystko, co Syn ma, otrzymuje od Ojca, w takim razie od Ojca ma również i to, że od Niego Duch Święty pochodzi. [...] Duch Święty principaliter, źródłowo, z Ojca pochodzi, a z Daru Ojca udzielonego Synowi - bez żadnej różnicy w czasie, communiter, wspólnie od Nich Obydwóch. Tylko wtedy nazywałby się On synem Ojca i Syna - co odrzucają od razu wszyscy zdrowo myślący - gdyby Oni Obaj Go zrodzili. Zatem Duch nie jest zrodzony przez dwie pozostałe Osoby Boskiej Trójcy, ale od Nich pochodzi” ${ }^{38}$. Mówiąc o pochodzeniu Ducha Świętego należy także pamiętać, że nie ma ono żadnego związku z następstwem czasowym. Jest ono bowiem ponadczasowe, tak jak ponadczasowe jest zrodzenie Syna.

\section{Duch Święty - Miłość łącząca Ojca i Syna}

Na różne sposoby biskup Hippony stara się wykazać, że trzecia Osoba Trójcy jest Miłością dwóch pierwszych Osób. O ile za najbardziej twórczy i oryginalny sposób orzekania o Deus-Trinitas, przyjmuje się zauważone przez Augustyna obrazy Trójcy w duszy człowieka, zwłaszcza w jego sferze psychologicznej ${ }^{39}$, to w całościowym ujęciu należy zwrócić uwagę na jeden z jego wniosków: „Czy tak, jak w tych wszystkich wypadkach widzimy bezsprzeczne triady - bo po-

${ }^{36}$ Augustyn, O Trójcy Świętej xv.19.36, s. 506.

37 Augustyn, O Trójcy Świętej Xv.17.29, s. 498.

${ }^{38}$ Augustyn, O Trójcy Świętej xv.26.47, s. 520-521.

39 Może to być np.: duch, wiedza i miłość (mens, notitia et amor); pamięć, rozumienie i wola (memoria, intelligentia et voluntas). Por. L. Bouyer, Duch Święty Pocieszyciel..., s. 265; W. Eborowicz, Rzut oka..., s. 203-205; A. Żurek, Ojcowie Kościoła..., s. 246. 
wstają one i są w nas, kiedy przypominamy sobie, widzimy i chcemy takich rzeczy - czy w ten sam sposób widzimy Boga Trójcę Świętą? Bo i tam także widzimy umysłem Mówiącego i Słowo Jego, to jest Ojca i Syna oraz pochodzącą z Nich obu Miłość, która jest im wspólna, to znaczy Ducha Świętego. Te triady dotyczące naszych zmysłów albo duszy widzimy raczej, niż w nie wierzymy, podczas gdy w to, że Bóg jest Trójcą, bardziej wierzymy, niż widzimy"40. Inna istotna różnica pomiędzy triadami a samą Trójcą wyraża się w tym, że każda z nich w człowieku jest jedynie częścią jego bytu, podczas gdy w Bogu Trójca jest Jego istotą, jest trzema równymi sobie i współistotnymi Osobami.

Duch Święty tym różni się od Ojca i Syna, że uosabia w sobie communitas amborum. „Bo czy to jako jedność Obu pozostałych Osób, jako Ich świętość, jako Ich miłość, czy też jako Ich jedność w miłości, lub jako Ich miłość w świętości - z wszelką pewnością nie jest On którąś z dwóch pierwszych Osób, ale jest tym, co Je łączy, przez co Syn jest umiłowany przez Rodziciela i wzajemnie Go miłuje. Przez Niego zachowują Oni «jedność ducha złączeni węzłem pokoju» (Ef 4,3), nie z uczestnictwa, lecz substancjalnie, nie z daru kogoś wyższego, lecz z Ich własnej wspólnej woli. Także i nam przykazano naśladować to w porządku łaski tak w stosunku do Pana, jak i wzajemnie pomiędzy nami. «Na tych dwóch przykazaniach całe Prawo zawisło i Prorocy» (Mt 22,40)"41.

Miłość, jaką jest Duch Święty, to Miłość, która jest Bogiem, z Boga pochodzi i wyraża wzajemne udzielanie się Ojca i Syna. „Tak więc Pismo św. głosi, że «Bóg jest miłością»; jeśli ta miłość jest z Boga, jeśli jej działanie sprawia w nas to, że trwamy w Bogu, a Bóg w nas i jeśli wreszcie ta immanencja świadczy o tym, że Bóg nam udzielił ze swojego Ducha, to znaczy, że Duch Święty jest Bogiem Miłością. Co więcej: ponieważ wśród darów Bożych nie ma daru większego niż miłość, a z drugiej strony nie ma większego daru Bożego niż Duch Święty, to czyż nie należy z tego wnosić, że Duch Święty jest miłością, która zarazem i jest Bogiem, i z Boga pochodzi? I jeśli miłość, którą Ojciec miłuje Syna i Syn miłuje Ojca, w niewymowny sposób wyraża ich wzajemne udzielanie się, to cóż jest stosowniejszego nad to, żeby ten, który jest wspólnym Duchem Ich obydwóch zwał się w ścisłym znaczeniu miłością? Oczywiście wierzymy i rozumiemy, że nie tylko Duch Święty jest miłością w Trójcy Świętej,

${ }^{40}$ Augustyn, O Trójcy Świętej xv.6.10, s. 470-471.

${ }^{41}$ Augustyn, O Trójcy Świętej IV.5.7, s. 224. 
ale niebezpodstawnie przypisuje Mu się, jako Jemu właściwe miano Miłości z powyżej wymienionych przyczyn" ${ }^{\prime 2}$.

Nawet jeśli Miłość jest imieniem własnym Ducha Świętego, to nie przestaje ona być miłością istotową. Wyjaśnia Augustyn: „Gdyby jednak w Trójcy Świętej tylko Duch Święty był Miłością, to logicznie Syn musiałby pochodzić jako Syn nie tylko od Ojca, ale także od Ducha Świętego. W niezliczonych bowiem tekstach jest powiedziane i czytamy, że Syn jest Jednorodzonym Synem Boga Ojca. Lecz musi to być zgodne z tym, co święty Apostoł mówi o Bogu Ojcu «który wyrwał nas z mocy ciemności i przeniósł do królestwa Syna swojej miłości» $($ Kol 1,13). Nie powiedział: «Do królestwa swego Syna». Gdyby tak powiedział, wyraziłby świętą prawdę, jak to zresztą często mówi, i bardzo słusznie. Ale powiedział: «do królestwa Syna swojej miłości». To znaczyłoby, że Syn Jego jest także Synem Ducha Świętego, jeśli przyjmiemy, że tylko Duch Święty jest miłością w Trójcy Świętej. Lecz ponieważ takie twierdzenie jest bardzo nie na miejscu, trzeba przyjąć, że nie tylko Duch Święty jest miłością w Trójcy Świętej $\mathrm{z}$ racji już dostatecznie wyjaśnionych - że miłość jest imieniem własnym Ducha Świętego. A co do wyrażenia: «Syn jego miłości», to trzeba je rozumieć jako «Syn jego ukochany» albo ostatecznie: «Syn jego substancji». Bo miłość Ojca w Jego naturze niewymownie prostej - tyle znaczy, co Jego natura i substancja, jak już często to podkreśliłem i niezmordowanie potwierdzać będę. Zatem «Syn jego miłości», jak Syn zrodzony z jego substancji”"33. Pomimo że Duch Święty różni się całkowicie od Ojca i Syna, to zarazem łączy Ich obu. „Bo czy to jako jedność Obu pozostałych Osób, jako Ich świętość, jako Ich miłość, czy też jako Ich jedność w miłości, lub jako Ich miłość w świętości - z wszelką pewnością nie jest On którąś z dwóch pierwszych Osób, ale jest tym, co Je łączy, przez co Syn jest umiłowany przez Rodziciela i wzajemnie Go miłuje"44.

\section{Co wyraża imię własne Ducha Świętego?}

Trzecia Osoba Trójcy ma swoje imię, tj. „Duch Święty”45. Nawiązując do ludzkiego sposobu wyrażania się, „Kiedy mówimy dar dawcy albo dawca daru,

${ }^{42}$ Augustyn, O Trójcy Świętej xv.19.37, s. 506-507.

43 Augustyn, O Trójcy Świętej xv.19.37, s. 507.

${ }^{44}$ Augustyn, O Trójcy Świętej vi.5.7, s. 224.

45 Jest to ten sam Duch Święty, który w Piśmie Świętym nazywany jest: Paracletus, Spiritus Vitae, Spiritus Veritatis, Spiritus Dei, Spiritus Christi, Spiritus Domini, Spiritus Patris. 
to tak jedno, jak drugie, wyraża wzajemne odnoszenie się. Zatem Duch Święty jest jakąś niewysłowioną wspólnotą (communio) Ojca i Syna. I może właśnie dlatego posiada to imię, że można je stosować i do Ojca, i Syna, ponieważ jako imię własne wyraża to, co jest dla Nich wspólne, bo i Ojciec, i Syn jest Duchem, i Ojciec, i Syn jest święty. Więc Duch Święty nazywa się Darem Ich Obu, żeby przez to imię, które Obu odpowiada, wyrażała się Ich wzajemna wspólnota” ${ }^{36}$. W imieniu własnym Ducha Świętego kryje się też pewna specyfika, otóż „mówiąc o relatywnym charakterze imienia Ducha Świętego (nie jako Trójcy, ale Tego, który jest w Trójcy), nie możemy wymienić Jego odpowiednika w relacji. Nie możemy bowiem wskazać tu takiej odpowiedniości w odnoszeniu się, jak kiedy mówimy: sługa pana, pan sługi, syn ojca, ojciec syna. Mówimy wprawdzie Duch Święty Ojca, ale nie mówimy odwrotnie: Ojciec Ducha Świętego, bo mogłoby się wydawać, że Duch Święty jest Jego synem. Tak samo mówimy o Duchu Świętym Syna, lecz nie mówimy Syn Ducha Świętego, żeby nie rozumiano tego tak, jakby Duch Święty był Jego Ojcem. Rzeczywiście w wielu relacjach zdarza się, że nie ma terminów wzajemnie sobie odpowiadających, które by się do siebie odnosiły" 47 .

\section{Związek Ducha Świętego z miłością potwierdza Pismo Święte}

Prawda o tym, że Ducha Świętego właściwie nazywamy miłością, podczas gdy w sensie ogólniejszym również Ojciec i Syn są miłością, nie wynika tylko z teoretycznych rozważań Augustyna, ale ma potwierdzenie w Piśmie Świętym. Biskup Hippony zauważa, że w pierwszej kolejności „musimy pilnie badać Ewangelię św. Jana, by znaleźć w niej miejsce, gdzie Duch Święty został nazwany miłością. Po słowach: «Najmilsi, miłujmy się wzajemnie, bo miłość jest z Boga», Ewangelista dodaje: «Kto ma miłość, życie swe z Boga ma i zna Boga. Kto nie ma miłości, Boga nie zna; bo Bóg jest miłością». Jest jasne, że Apostoł o tej samej miłości mówi, że jest Bogiem i że jest z Boga. Ale ponieważ i Syn z Boga Ojca się narodził, i Duch Święty od Boga Ojca pochodzi, przeto nie bez racji możemy zapytać, do którego $z$ Nich raczej zastosować słowa mówiące, że Bóg jest miłością. Tylko Ojciec jest Bogiem, ale nie «z Boga». Zatem miłością, która jest Bogiem i z Boga pochodzi, może być tylko Syn albo Duch

${ }^{46}$ Augustyn, O Trójcy Świętej v.11.12, s. 209.

47 Augustyn, O Trójcy Świętej v.12.13, s. 209. 
Święty. Otóż w dalszym ciągu tego samego tekstu, mówiąc o miłości Bożej, nie tej, którą my Boga kochamy, lecz którą «Bóg umiłował nas i posłał Syna swego jako ofiarę przebłagania za grzechy nasze», Apostoł upomina nas, żebyśmy się wzajemnie miłowali, i chcąc to dokładniej wyjaśnić, powiada: «Że w nim mieszkamy, a on w nas, poznajemy po tym, że udzielił nam z Ducha swego». Więc to Duch Święty, z którego udzielił nam, sprawia, że mieszkamy w Bogu, a Bóg w nas. To właśnie sprawia miłość. A wreszcie, powtórzywszy to jeszcze, że «Bóg jest miłością», zaraz dodaje: «A kto trwa w miłości, w Bogu mieszka i Bóg w nim», jak przedtem powiedział: «Że w nim mieszkamy, a On w nas, poznajemy po tym, że udzielił nam z Ducha swego». A więc Ducha Świętego oznaczają słowa: «Bóg jest miłością». Zatem Duch Święty, Bóg pochodzący z Boga, kiedy zostaje dany człowiekowi, rozpala w nim miłość ku Bogu i bliźnim, będąc sam miłością. Istotnie, człowiek nie ma czym Boga miłować, jeśli nie otrzyma tego od Boga. Toteż Apostoł mówi: «My miłujemy Boga, ponieważ On nas pierwszy umiłował» (1 J 4,7-19). A Apostoł Paweł powiada: «Miłość Boża rozlana jest w sercach naszych przez Ducha Świętego, który nam dany został» $(\mathrm{Rz} 5,5){ }^{\prime \prime 4}$.

\section{Dar miłości otrzymywany od Ducha Świętego}

Duch Święty, który jest w Trójcy Miłością - Darem niestworzonym, znajduje swoje odzwierciedlenie w historii zbawienia. Podobnie jak inni autorzy, w tym zwłaszcza biskup Mediolanu ${ }^{49}$, również Augustyn koncentruje się na niewypowiedzianym bogactwie daru stworzongo, jakim jest płynące od Ducha Świętego, jak ze źródła, wszelkie obdarowanie wobec stworzeń, a zwłaszcza Kościoła ${ }^{50}$. Pod szczególnym natchnieniem apostoła Pawła przyznaje biskup Hippony: „Żaden z darów Bożych nie jest bardziej doskonały niż ten dar miłości. On jeden pozwala rozróżnić synów królestwa i synów wiecznego zatracenia. Duch Święty daje również i inne dary, lecz bez miłości nie służą one na nic. Komu Duch Święty nie udzieli tego, że stanie się on miłośnikiem Boga i bliźniego,

${ }^{48}$ Augustyn, O Trójcy Świętej xV.17.31, s. 500-501.

49 Por. A. Strzelecka, Nauka św. Ambrożego o Duchu Świętym, „Vox Patrum” 8 (1988) z. 15, s. 763 .

${ }^{50}$ Por. Y. Congar, Wierzę w Ducha Świętego. Duch Święty w „ekonomii”..., s. 132-133; E. Te-Selle, Spirito Santo, s. 1322-1323; A. Żurek, Duch Święty a powołanie do kapłaństwa w Kościele starożytnym, „Scripture Lumen” 8 (2016), s. 265; A. Żurek, Ojcowie Kościoła..., s. 250; A. Żurek, Pierwsze wieki Kościoła, Tarnów 2007, s. 154. 
ten nie zostanie przeniesiony $\mathrm{z}$ lewicy na prawicę. I nie $\mathrm{z}$ innych racji Duch Święty właśnie zwie się Darem, jak z racji miłości. A jeśliby jej ktoś nie miał, to nawet gdyby mówił językami ludzkimi i anielskimi, byłby jedynie spiżem dźwięczącym lub cymbałem brzmiącym; i choćby miał wszelką wiarę, tak iżby góry przenosił, niczym jest; i choćby ciało płomieniom wydał, na nic mu się nie przyda (1 Kor 13,1-3)" . Podobnie też, co do samego sposobu, w jaki trynitarna miłość otwiera się i w pewnym sensie przechodzi na stworzenie, Augustyn przywołuje apostoła Pawła ( $\mathrm{Rz} 5,5)$, i reasumuje: „Zatem miłość, która jest z Boga i jest Bogiem, w ścisłym znaczeniu jest Duchem Świętym. Przez Niego rozlana jest w sercach naszych miłość Boża, przez którą jest nam dana cała Trójca Święta. Toteż bardzo słusznie Duch Święty, będący Bogiem, jest także nazywany Darem Bożym (Dz 8,20). Przez Dar należy rozumieć właśnie miłość, która doprowadza do Boga, lecz której żaden inny dar do Boga nie doprowadza" ${ }^{\prime 2}$. Duch Święty jest źródłem i sprawcą jedności, łącząc ludzi z Bogiem i między sobą.

\section{Podsumowanie}

Wprawdzie pragnienie wyjaśnienia obecności Ducha Świętego w Boskiej Trójcy przewija się przez całe De Trintate Augustyna, to jednak nie zawsze, a tym bardziej nie od razu jest ono wiązane z miłością. Rozróżnienie w wewnętrznym życiu Trójcy pomiędzy miłością istotową, wspólną trzem Osobom Boskim, a miłością osobową, którą jest Duch Święty jako Miłość, jako Dar wzajemny Ojca i Syna, należy uznać za jeden z najbardziej prekursorskich elementów pneumatologii Augustyna. Wyrosła na gruncie biblijnym i sprecyzowana przez Augustyna na płaszczyźnie spekulatywnej koncepcja Ducha Świętego jako Osoby-Miłości, tak zresztą jak i Osoby-Daru, pozostawi swój trwały ślad w chrześcijańskiej myśli teologicznej Zachodu.

W kontekście najbardziej oryginalnej dla traktatu De Trinitate trynitologii „psychologicznej”, która jest sposobem orzekania o wewnętrznym życiu Trójcy Świętej na podstawie analogii do duszy, a zwłaszcza do psychologicznej sfery człowieka, bardziej zrozumiały staje się także związek duszy z Bogiem poprzez miłość. Miłość staje się dla myśliciela z Tagasty swoistą metodą poznania, gdyż

\footnotetext{
${ }^{51}$ Augustyn, O Trójcy Świętej xv.18.32, s. 501. Por. A. Żurek, Duch Święty..., s. 43.

${ }^{52}$ Augustyn, O Trójcy Świętej xv.18.32, s. 502. Por. S. Jaśkiewicz, Ecce Trinitas..., s. 28; A. Żurek, Duch Święty..., s. 42.
} 
człowiek, doświadczając jej, zauważa, że jej źródło nie jest w nim. Szuka jej więc nie w sobie, a tym bardziej nie w otaczającym go świecie, ale tam, gdzie jest ona samoistna i zawsze równa sobie. Miłość jest więc ostatecznie drogą prowadzącą do poznania Boga Trójcy, który w swym wewnętrznym życiu jest miłością istotową, a w Osobie Ducha Świętego miłością osobową.

Augustyn koncentruje swoją uwagę na miłości, bo to ona pozwala mu odpowiedzieć na jedno z najtrudniejszych pytań, jakim jest pytanie nie tylko o Ducha Świętego, ale i o samą troistość w Bogu. Choć z jednej strony tajemnicy Boga nie da się sprowadzić do liczb czy poprzez liczby jej wypowiedzieć, to jednak uświęcone tradycją „trzy Osoby” stają się nam bliższe właśnie dzięki miłości, gdyż jest Ich tylko Troje, bo jeden jest miłujący Tego, który z Niego pochodzi (Ojciec miłuje Syna), jeden miłujący Tego, z którego pochodzi (Syn miłuje Ojca), i sama Ich miłość (Duch Święty). Duch Święty nie jest owocem miłości Ojca i Syna, ale żywą Ich więzią, stąd może być nazywany w sposób najbardziej odpowiedni Miłością. Ponieważ Duch Święty jest Duchem Ojca i Duchem Syna, jest więzią miłości, która łączy Ojca z Synem, Duch Święty jest miłością osobową w Trójcy Świętej, i to Jemu przysługuje bezpośrednio imię Miłość. Miłość osobowa, jaką jest Duch Święty, nie stoi w sprzeczności z wewnętrznym życiem Boga Trójcy i Jego miłością istotową.

Choć już Grzegorz z Nazjanzu mówił o przypisywaniu przez Pismo Święte „imion Bożych” Duchowi Świętemu, to jednak na Zachodzie właśnie Augustyn podjął się ich wyjaśnienia również w oparciu o wewnętrzne życie Trójcy. Duch Święty w odniesieniu do stworzenia, jak wynika to z licznych tekstów biblijnych, jest wspólnym darem Ojca i Syna, właśnie dlatego, że w wewnętrznym życiu Deus-Trinitas jest wzajemnym Darem Ojca i Syna. W ten sposób trzecia Osoba Trójcy, której imienię własne brzmi Duch Święty, jest również właściwie nazywana Miłością i Darem.

\section{Bibliografia}

Augustyn, O Trójcy Świętej, tłum. M. Stokowska, Kraków 1996.

Augustyn, O wielkości duszy (tłum. D. Turkowska), w: Św. Augustyn. Dialogi filozoficzne, oprac. W. Seńko, Kraków 2001, s. 339-420.

Bartnik C. S., Dogmatyka katolicka, t. 1, Lublin 2000.

Bolgiani F., Spirito Santo, w: Dizionario patristico e di antichità cristiane, diretto da A. Di Berardino, t. 2, Casale Monferrato 1983, kol. 3285-3298. 
Bouyer L., Duch Święty Pocieszyciel. Duch Święty i życie w łasce, tłum. A. Liduchowska, Kraków 1998.

Chadwick H., Augustyn, tłum. T. Szafrański, Warszawa 2000.

Congar Y., Wierzę w Ducha Świętego. Duch Święty w „ekonomii”. Objawienie i doświadczenie Ducha, t. 1, tłum. A. Paygert, Warszawa 1995.

Częsz B., Pneumatologia Ojców Kościoła, w: Duch, który jednoczy. Zarys pneumatologii, red. M. Marczewski, Lublin 1998, s. 211-232.

Eborowicz W., Rzut oka na pneumatologię św. Augustyna, „Vox Patrum” 8 (1988) t. 14, s. 197-206.

Jaśkiewicz S., „Ecce Trinitas Deus meus, Pater et Filius et Spiritus Sanctus”. Nauka o Boskiej Trójcy na podstawie „Wyznañ” św. Augustyna, „Collectanea Theologica” 78 (2008) $\mathrm{nr}$ 1, s. 5-30.

Jaśkiewicz S., O potrzebie i znaczeniu historii według świętego Augustyna, „Studia Regionalne" 1 (2007), s. 155-174.

Jaśkiewicz S., Św. Augustyn - poszukiwanie Boga, Katowice 2012.

Kijewska A., Święty Augustyn, Warszawa 2007.

Kowalczyk St., Człowiek i Bóg w nauce świętego Augustyna, Warszawa 1987.

Królikowski J., Dotknięci Duchem Świętym. Metafory pneumatologiczne w interpretacjach Ojców Kościoła, „Scripture Lumen” 8 (2016), s. 241-255.

O’Donnell J. J., Bibbia, w: Agostino. Dizionario enciclopedico, ed. A. Fitzgerald, edizione italiana a cura di L. Alici, A. Pieretti, Roma 2007, s. 298-303.

Studer B., Dio salvatore nei Padri della Chiesa, Roma 1986.

Strzelecka A., Nauka św. Ambrożego o Duchu Świętym, „Vox Patrum” 8 (1988) t. 15 , s. $759-765$.

TeSelle E., Spirito Santo, w: Agostino. Dizionario enciclopedico, ed. A. Fitzgerald, edizione italiana a cura di L. Alici, A. Pieretti, Roma 2007, s. 1321-1325.

Williams R., Trinitate, De, w: Agostino. Dizionario enciclopedico, ed. A. Fitzgerald, edizione italiana a cura di L. Alici, A. Pieretti, Roma 2007, s. 1396-1405.

Żurek A., Duch Święty a powołanie do kapłaństwa w Kościele starożytnym, „Scripture Lumen” 8 (2016), s. 258-267.

Żurek A., Duch Święty jako Dar i Miłość według świętego Augustyna, „Tarnowskie Studia Teologiczne 17 (1998), s. 37-46.

Żurek A., Ojcowie Kościoła - twórcy i świadkowie Tradycji, Tarnów 2013. Żurek A., Pierwsze wieki Kościoła, Tarnów 2007. 


\section{Streszczenie}

Potrzeba było wielu lat i związanych z nimi uporczywych poszukiwań, aby św. Augustynowi udało się przejść od „nieznanego” Boga do Boga nie tylko umiłowanego, ale i będącego samą Miłością. Jako „Wielki Nieznany” prezentował się bowiem początkującemu kapłanowi z Hippony Duch Święty, a objawiona prawda, że „Bóg jest miłością" ( $1 \mathrm{~J}$ 4, 8-16), trudna do pogodzenia z podstawową zasadą wiary o Trójcy Świętej, tj. o Bogu jedynym w swej istocie i troistym w Osobach. Problematyka pochodzenia i imienia „Duch Święty” znajduje obszerne omówienie w De Trinitate, i to tam zwłaszcza, w ostatniej księdze biskup Hippony wyjaśnia, z jakich powodów Ducha Świętego nazywamy zwłaszcza Jednością, Miłością i Darem.

\section{Słowa kluczowe}

Trójca Święta, De Trinitate św. Augustyna, Duch Święty, Dar, Jedność, Miłość

\section{Summary}

\section{The Holy Spirit as "Love" in Augustine's De Trinitate}

This article traces the role of the Holy Spirit throughout Augustine's De Trinitate. In God the name "Love" (amor) can be taken both with respect to the essence and with respect to a person. Insofar as it is taken with respect to a person, it is a proper name of the Holy Spirit in the same way that "Word" is a proper name of the Son. The Holy Spirit is, in the Holy Trinity, the love of Both, of the Father and of the Son. Augustinian thinking on the relationship of the Trinity can thus be summed up as Lover, Love and Beloved. Elsewhere he uses these terms to describe the relationship, but if the Father is the Father, the Son is the Word of God and the Holy Spirit is both the Gift of God and the Love of God, then the Father is the Lover, the Spirit is Love itself and the Son is the Beloved. In contrast with the dominant Western and Eastern traditions, for Augustine the Holy Spirit comes to be thought of as God in a privileged sense, that is, as the person of the Trinity who is the most proper bearer of certain privileged names of God, most notably Love.

\section{Keywords}

Holy Trinity, Holy Spirit, Love, Augustine's teaching, Pneumatology 